\title{
Apparent Origin of Glossopharyngeal, Vagus and Accessory Nerves: An Aspect to Consider in Human Neuroanatomy Teaching
}

\author{
El Origen Aparente de los Nervios Glosofaríngeo, Vago y Accesorio: \\ Un Aspecto para Considerar en la Enseñanza de Neuroanatomía Humana
}

Jorge Eduardo Duque'; Yobany Quijano²; John Barco' \& Edison Peralta²

\begin{abstract}
DUQUE, J. E.; QUIJANO, Y. ; BARCO, J. \& PERALTA, E. Apparent origin of glossopharyngeal, vagus and accessory nerves: An aspect to consider in human neuroanatomy teaching. Int. J. Morphol., 36(4):1337-1340, 2018.

SUMMARY: In various neuroanatomy texts and articles related to this area of knowledge, there is a conceptual vacuum associated with the precise sites where the roots of the cranial nerves emerge. The objective of the study was to establish the exact location of the apparent origin of the glossopharyngeal, vagus and accessory cranial nerves in the medulla oblongata of the human being 120 human brainstems, previously fixed in formalin solution at $10 \%$ were assessed, the location where such nerve roots emerge was identified by direct examination and once the piamater was removed at both right and left sides as it has been stated in the literature. It was found that in $100 \%$ of the studied brainstems their nerve roots emerge on average at about $2.63 \mathrm{~mm}$ behind the retro-olivary groove, different to what has been stated in the literature. Glossopharyngeal, vagus and accessory human nerves do not emerge directly from the retroolivary groove, as commonly reported; instead, they emerge behind the said groove, specifically in the retro-olivary groove area, where they form a continuous line of nerve roots.
\end{abstract}

KEY WORDS: Cranial nerves; Origin; Apparent; Estate; Groove; Olive grove.

\section{INTRODUCTION}

When teaching neuroanatomy, textbooks are used as common references for the general study of this field of morphology. These texts contain several assertions about the apparent origin of glossopharyngeal, vagus and accessory nerves. For example, the following descriptions are found for the glossopharyngeal nerve. In the retro-olivary groove (Arana \& Rebollo, 1979; Bustamante, 2007) or post-olivary fissure, the vagus nerve is found, which emerges behind the olive, as do the glossopharyngeal and accessory nerves (Carpenter, 1994). Along with the retro-olivary groove, a shallow groove located between the olive and the posterolateral surface of the bone, these three nerves emerge as a line of rootlets. The glossopharyngeal and vagus nerves emerge from the upper third of the backside of the olive (Arana \& Rebollo; Tubbs et al., 2011). The glossopharyngeal nerve arises from the posterior side of the olive as one or rarely two rootlets, caudal to the origin of the facial nerve (Bustamante). The glossopharyngeal nerve emerges between the inferior olive and the inferior cerebellar peduncle (Rubin \& Safdieh, 2007; Snell, 2014). This nerve emerges from the lateral sulcus of the medulla, caudal to the facial nerve (Kahle
\& Frotscher, 2003). The glossopharyngeal nerve emerges from the top of the posterior side groove (Carpenter; Legros et al., 2000; Coello \& Coello, 2009). The glossopharyngeal nerve is located in the retro-olivary groove (Arana \& Rebollo; Bustamante; Policeni \& Smoker, 2008; Sarrazin et al., 2013) or post-olivary groove (Fix \& High, 2000; Surek et al., 2010). IX nerve emerges behind the olive (Tubbs et al.). The glossopharyngeal nerve emerges from the posterior side of the olive in its upper third (Chatain \& Bustamante, 1986; Tubbs et al.). Glossopharyngeal nerve roots are located side of the medulla oblongata, between the inferior olive and the inferior cerebellar peduncle side. The glossopharyngeal nerve is located in the anterolateral region of the medulla oblongata (Drake et al., 2005; Latarjet \& Ruiz Liard, 2005).

The following descriptions are made with regard to the vagus nerve. The vagus nerve comes from the medulla oblongata, behind the olive (Sinelnikov, 1977) or lateral to it (Afifi \& Bergman, 2006; Monkhouse, 2006; Snell), or in the upper third of its side (Rubin \& Safdieh; Tubbs et al.). The vagus nerve emerges from the posterolateral sulcus of

\footnotetext{
${ }^{1}$ Department of Basic Sciences. Medicine. Universidad de Caldas, Manizales, Colombia.

${ }^{2}$ Department of Basic Sciences. Medicine. Universidad de Ciencias Aplicadas y Ambientales (UDCA), Bogota, Colombia.
} 
the medulla oblongata, below the glossopharyngeal nerve (Chatain \& Bustamante; Snell; Garcia-Porrero \& Hurlé, 2015). Vagus nerve fibers emerge from the retro-olive grove (Arana \& Rebollo; Bustamante; Policeni \& Smoker; Sarrazin et al.; Garcia-Porrero \& Hurlé, 2015) or post-olive fissure (Carpenter). The emergence of the vagus nerve occurs by the collateral sulcus bulb (Legros et al.; Coello \& Coello), between the glossopharyngeal and accessory nerves (Coello \& Coello). The vagus nerve is located in the lateral sulcus of the medulla, in the anterolateral region of the medulla oblongata (Sinelnikov; Afifi \& Bergman), the vagus nerve originates in the medulla (Legros et al.; Damodaran et al., 2014). Vagus nerve roots are located in the ventral-lateral part of the medulla oblongata, between the inferior olive and the inferior cerebellar peduncle below the glossopharyngeal nerve .The accessory nerve arises behind the olive (Arana \& Rebollo; Carpenter; Latarjet \& Ruiz Liard; Sarrazin et al.).

Finally, the origin of the accessory nerve is described as follows: cranial roots of accessory nerve emerge from the lateral side of the olives (Snell; Afifi \& Bergman), in its two lower thirds (Rubin \& Safdieh; Sarrazin et al.). The accessory nerve is located in the retro-olivary groove (Sarrazin et al.; Policeni \& Smoker). The accessory nerve becomes visible in the posterolateral sulcus, of the medulla oblongata (Chatain \& Bustamante; Policeni \& Smoker). The accessory nerve emerges from a groove that runs along the bulb behind the bulbar olive, immediately below the vagus nerve (Surek et $a l$.). The roots of the accessory nerve arise from a post-olive position. The posterior collateral sulcus is the location of origin of the accessory nerve (Legros et al.; Coello \& Coello). The accessory nerve emerges from the lateral sulcus of the medulla oblongata, below the vagus nerve (Testut \& Latarjet, 1949).

In addition to the anatomical literature previously cited, in a different anatomy atlas the retro-olive groove is appointed as the apparent origin of the glossopharyngeal, vagus and accessory nerves (Higashida, 2001).

\section{MATERIAL AND METHOD}

A macroscopic descriptive study was performed on 120 adult human brainstems (240 retro-olive grooves), previously fixed with formalin solution at $10 \%$, from the Anatomy laboratories of the Autonoma University of Manizales, Universidad de Caldas and University of Applied and Environmental Sciences. This aimed to identify the apparent origin of the glossopharyngeal, vagus and accessory nerves in the medulla oblongata. Those parts exhibiting any deformation were not included. By dissection, the pia mater was removed to expose the areas of interest, mainly the retro-olivary groove area on left and right sides. Then, a direct inspection was performed to verify the exact location where the roots of the glossopharyngeal, vagus and accessory nerves arise in the medulla oblongata. A digital calibrator was used to measure, in millimeters, the distance between the retro-olivary groove and the location where the nerve roots emerge. Finally, photographic records of the prepared pieces were made.

Ethical Considerations. Material amphitheaters Department of Biological Basic Sciences at the Autonoma University of Manizales, Universidad de Caldas and the Faculty of Medicine of the University of Applied and Environmental Sciences (UDCA) Bogota (Colombia) was used in carrying out this work, which was obtained based strictly on legal medical criteria contained in decree 786 of 1990 of Colombia. In addition, all the principles of the declaration of Helsinki for medical research were followed, ensuring respect to the parts obtained in the study and confidentiality of the data of the deceased, their dignity and Integrity treatment.

\section{RESULTS}

Out of the 120 brainstems studied, it was found that in all of them, namely $100 \%$ of the neuro-anatomical pieces, corresponding to 240 retro-olivary grooves, the apparent source of the glossopharyngeal, vagus and accessory nerves, form a continuous line of nerve fibers that emerges from the medulla oblongata, oriented from top to bottom. Such condition occurs exactly behind the retro-olivary groove and not on it, as is often reported in the literature. In our work, we find that the left side nerve roots emerge $2.66 \mathrm{~mm}$ on average behind the retro-olivary groove, whereas the nerve roots of the right side emerge $2.61 \mathrm{~mm}$, on average (Fig. 1).

\section{DISCUSSION}

Knowledge of the cranial nerves is essential for students in various health professions, among others, because of its intricate structure and functional aspects (Dickson \& Stephens, 2015). Besides these aspects, the ones concerning the use of texts that are incorporated into the teaching of this topic should be considered, because multiple authors indicate that the apparent origin of the glossopharyngeal, vagus and accessory nerves are found in the retro-olivary groove (Arana \& Rebollo; Bustamante; Policeni \& Smoker; Sarrazin et al.) or post-olivary groove (Carpenter; Surek et $a l$.), however, a more detailed inspection of the site of origin, as it was verified in this work reveals that such a description is not accurate. 


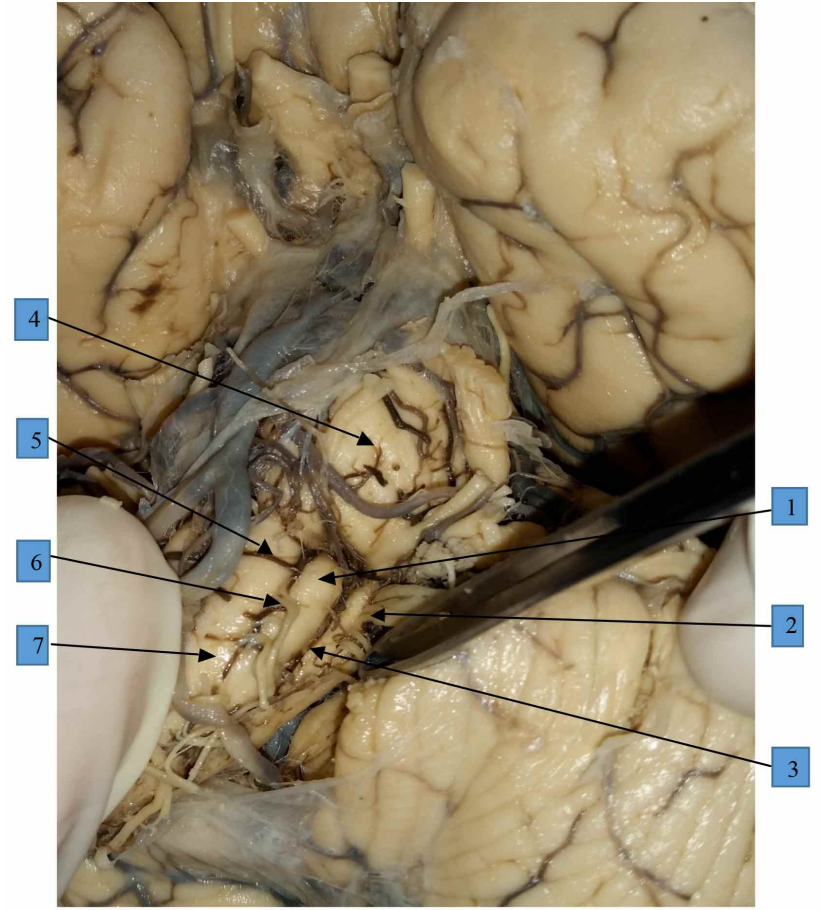

Fig. 1. The nerve roots of the glossopharyngeal, vagus and accessory nerves forming a continuous line located in the retro-olivary area, not in the groove. 1. Olive, 2. nerve roots of the glossopharyngeal, vagus and accessory nerves, 3. retro-olivary groove, 4.boss, 5. Pyramid, 6. hypoglossal nerve, 7. Oblong medulla.

In the brainstem used for this work, it was found that in none of them the nerve roots of these cranial nerves emerge from the retro-olivary grooves. In $100 \%$ of neuroanatomical parts analyzed, it was shown that the nerve roots make their appearance, both right and left, about $2.63 \mathrm{~mm}$ on average after the retro-olivary groove, particularly in the retro-olivary areas, without regard to the presence of any groove. Two of the referenced authors indicate that these three nerves originate in the posterior collateral groove of the medulla oblongata (Legros et al.; Coello \& Coello). However, in our study we did not find the presence of such a groove and, on the other hand, in the Terminologia Anatomica is not registered this term (Terminologia Anatomica, 1998). It can also be seen that when two- dimensional images for teaching cranial nerves are used (Dickson \& Stephens) in the texts, the subjective impression ofit being located in the retro-olivary groove is given, so it is necessary to corroborate what is indicated in texts by actual practices with brainstem, so there is no limitation in the use of two- dimensional images (Dickson \& Stephens), as the demonstration by experimentation is an intelligent practical theoretical exercise, that allows students to undertake more objective and effective learning (Duque Parra \& Barco Ríos, 2013).
Since neuroanatomical knowledge is of great importance in the training of health care students and specialists such as neurosurgeons, it is important to venture to the edge of the known universe of anatomical education (Paalman, 2000), part of which is emphasized in the text of teaching in university education, which in turn may limit its approach with a poor description of certain neuroanatomical aspects that require high precision in the neurosurgical field, as in this case with the apparent origin of the glossopharyngeal, vagus and accessory nerves.

\section{CONCLUSIONS}

In human brainstems, the nerve roots of the glossopharyngeal, vagus and accessory nerves have their origin apparently about $2.63 \mathrm{~mm}$, on average, behind the retro-olivary groove, not directly over the groove as reported in the literature. At this point, the nerve roots form a continuous line located in retro-olivary areas, without evidence of any groove, as it is also reported in the literature. Therefore, the use of two-dimensional images for teaching neuroanatomy can lead to misinterpretations on the origin of the cranial nerves, added to this the use of some terms that are not registered in official Terminology Anatomical.

DUQUE, J. E.; QUIJANO, Y. ; BARCO, J. \& PERALTA, E. El origen aparente de los nervios glosofaríngeo, vago y accesorio: un aspecto para considerar en la enseñanza de neuroanatomía humana. Int. J. Morphol., 36(4):1337-1340, 2018.

RESUMEN: En diversos textos de neuroanatomía y artículos relacionados con esta área del conocimiento, se evidencia un vacío conceptual asociado con los sitios precisos por donde emergen los pares craneales. El objetivo de este estudio fue stablecer la ubicación exacta del origen aparente de los nervios craneales glosofaríngeo, vago y accesorio en el bulbo raquídeo de 120 tallos cerebrales humanos, previamente fijados en solución de formalina al $10 \%$. Fueron evaluados, el lugar donde surgen tales raíces nerviosas se identificó mediante examen directo y una vez que se retiró la piamadre tanto en el lado derecho como en el izquierdo como se ha dicho en la literatura. Se encontró que en el $100 \%$ de los troncos cerebrales estudiados, sus raíces nerviosas emergen en promedio a unos 2,63 mm detrás del surco retroolivar, diferente a lo que se ha dicho en la literatura. Los nervios humanos glosofaríngeos, vago y accesorio no emergen directamente de la ranura retroolivar, como se informa comúnmente, sino que emergen detrás de dicha ranura, específicamente en el área de surco retroolivar, donde forman una línea continua de raíces nerviosas.

PALABRAS CLAVE: Nervios craneales; Origen; Aparente; Raíces; Surco; Olivar. 


\section{REFERENCES}

Afifi, A. K. \& Bergman, R. A. Neuroanatomía Funcional. Ciudad de México, McGraw Hill Interamericana, 2006. pp.494.

Arana, I. R. \& Rebollo, M. A. Neuroanatomía. $7^{\text {a }}$ ed. Buenos Aires, InterMédica, 1979

Bustamante, J. Neuroanatomía Funcional y Clínica. $4^{\mathrm{a}}$ ed. Bogotá, Celsus, 2007. pp.530.

Carpenter, M. B. Neuroanatomía. Fundamentos. $4^{\mathrm{a}}$ ed. Madrid, Médica Panamericana, 1994. pp.293.

Chatain, I. \& Bustamante, J. Anatomía Macroscópica Funcional y Clínica. Wilmington, Addison Wesley Iberoamericana S. A., 1986. pp.820.

Coello, C. R. \& Coello, S. R. Anatomía Humana. $2^{\text {a }}$ ed. Guayaquil, Universidad de Guayaquil, 2009. pp.524.

Damodaran, O.; Rizk, E.; Rodriguez, J. \& Lee, G. Cranial nerve assessment: a concise guide to clinical examination. Clin. Anat., 27(1):25-30, 2014.

Dickson, K. A. \& Stephens, B. W. It's all in the mime: Actions speak louder than words when teaching the cranial nerves. Anat. Sci. Educ., 8(6):58492, 2015.

Drake, R. L.; Vogl, W. \& Mitchell, A. W. Gray. Anatomía para Estudiantes. Madrid, Elsevier, 2005. pp.1161.

Duque Parra, J. E. \& Barco Ríos, J. Enseñanza de la ciencia sin experimentación por demostración versus enseñanza por virtualización de la experimentación. Arch. Med., 13(2):226-32, 2013.

Fix, J. D. \& High, Y. Neuroanatomy. Philadelphia, Lippincott Williams \& Wilkins, 2000. pp.142.

Higashida, H. B. Atlas de Anatomía Humana. Ciudad de México, McGrawHill Interamericana. 233, 2001

Latarjet, M. \& Ruíz Liard, A. Anatomía Humana. Buenos Aires, Médica Panamericana, 2005. pp.1746.

Legros, B.; Fournier, P.; Chiaroni, P.; Ritz, O. \& Fusciardi, J. Basal fracture of the skull and lower (IX, X, XI, XII) cranial nerves palsy: four case reports including two fractures of the occipital condyle--a literature review. J. Trauma, 48(2):342-8, 2000.

Monkhouse, S. Cranial Nerves Functional Anatomy. Cambridge, Cambridge University Press, 2006. pp.147.

Moore, K. L.; Dalley, A. F. \& Agur, A. M. R. Clinically Oriented Anatomy. 6th ed. Philadelphia, Wolters Kluwer/Lippincott Williams \& Wilkins, 2010 .

Paalman, M. H. New frontiers in anatomy education. Anat. Rec. (New Anat.), 261(2):47, 2000.

Policeni, B. A. \& Smoker, W. R. Pathologic conditions of the lower cranial nerves IX, X, XI, and XII. Neuroimaging Clin. N. Am., 18(2):347-68, 2008 .

Rubin, M. \& Safdieh, J. S. Netter's Concise Neuroanatomy. Philadephia, Saunders Elsevier, 2007. pp.403.

Sarrazin, J. L.; Toulgoat, F. \& Benoudiba, F. The lower cranial nerves: IX, X, XI, XII. Diagn. Interv. Imaging, 94(10):1051-62, 2013.

Sinelnikov, R. D. Atlas de Anatomía Humana. Tomo III. Moscú, MIR, 1977. pp.400.

Snell, R. S. Neuroanatomía Clínica. $7^{\text {a }}$ Ed.. Madrid, Médica Panamericana, 2014. pp.541.

Surek, C. C.; Van Ess, M. \& Stephens, R. Acousticofacial-glossopharyngeal triangle: an anatomic model for rapid surgical orientation. Skull Base, 20(3):139-42, 2010.

Testut, L. \& Latarjet, A. Tratado de Anatomía Humana. Tomo Tercero. Barcelona, Salvat Editores, 1949. pp.1190.

Tubbs, R. S.; Mortazavi, M. M.; Loukas, M.; Shoja, M. M. \& Cohen-Gadol, A. A. Intraoperative and anatomical descriptions of intracranial connections between the glossopharyngeal and vagus nerves: clinical implications. J. Neurosurg., 115(1):179-81, 2011.
Corresponding author:

Yobany Quijano Blanco

Department of Basic Sciences Medicine

Universidad de Ciencias Aplicadas y Ambientales

calle 222 No. 54-37

Bogotá

COLOMBIA

Email: globdimorf@udca.edu.co

Received: 10-04-2018

Accepted: 28-06-2018 